\title{
MANUEL VÁZQUEZ MONTALBÁN
}

Luis Artigue

La gran derrota que ha sufrido la izquierda últimamente en España es la muerte de Manuel Vázquez Montalbán. Al lado de esa noticia el pucherazo evidente e indemostrable de la Asamblea de Madrid no pasa de ser una leve nimiedad. La muerte: esa puta lasciva.

Se nos ha muerto como del rayo un hombre, una pluma, una mirada, una luz que nos hacía falta y sin la cual este país se queda un poco más a la intemperie; un poco más a oscuras. Y sin embargo ahora yo no voy a hacer una elegía, pues el pasado martes don Victoriano Crémer escribió su columna sobre este tema de forma tan lírica y conmovedora que me dan ganas de cederle este espacio, que es el suyo, para que hoy la repita.

De todos modos quiero compartir dos pensamientos que el inesperado fallecimiento de este escritor me ha suscitado; dos mensajes morales o, mejor dicho, humanos. El primero es evidente: su ejemplo. Alguien que no se calla, que no se pliega, que no se vende va y se nos marcha para siempre acaso diciéndonos que ahora nos toca a nosotros. Que todo tiene sentido si de alguna forma se perpetúa. Que corren viejos tiempos para este país. Que volvemos atrás. Que frente a los nacionalismos internos este Gobierno tan poco de centro está contraponiendo su versión mimética del nacionalismo español. Que se compran y venden los votos y las almas en los cuartos oscuros. Que los políticos parecen creadores de ficción... Y viendo eso no debemos apalancamos en nuestro papel de espectadores, de sufridores; es preciso no callamos, no conformarnos, no es suficiente ni inteligente lo de que cada palo aguante su vela.

Bush, Aznar, Rajoy, Blair y el resto de mentes clónicas de ahí arriba eran contrarrestadas por el pensamiento de Manuel Vázquez Montalbán. Ahora se ha muerto, acaso para enseñamos que corren tiempos en los que la indiferencia y la apatía son un cáncer cívico; tiempos en los que se hace preciso tener una conciencia global de uno mismo y del mundo, y atesorar principios claros y personales defendidos con agallas.

El otro mensaje que la muerte de este hombre me ha enseñado es Antonio Pereira. Sé que suena raro, pero qué le voy a hacer. Casi me enteré a la vez por boca de unos amigos: que se ha muerto Vázquez Montalbán, y que Antonio Pereira está 
hospitalizado aquí en León. Luego empezaron críticos y políticos, profesores y cantantes a entonar odas en tomo a un cadáver, pero nadie decía nada de Antonio Pereira, claro. Pues quiero decirlo yo. No es necesario sino cruel esperar a que los grandes hombres se mueran para expresarles nuestro reconocimiento $y$ agradecimiento. Ni mucho menos.

Querido abuelo Antonio Pereira, ponte bueno porque nos haces falta, porque tu ironía es una luz fabulosa que ilumina el mundo, porque tu compañía es una bendición sacra que apreciamos. Yo personalmente necesito saber que sigues por ahí, que continúas escribiendo cuentos sobre una mesa-camilla, como Unamuno. Necesito que me mandes callar, que me pidas que trabaje la humildad, que me eches la bronca ingeniosamente por mis salidas de tono o que, con tus silencios no muy frecuentes, me enseñes la sagrada lección de cuánto me queda aún que aprender de mis mayores.

Hay seres humanos que tienen respuestas o se las inventan, hombres dotados con una luz germinal que les hace propicios para eso tan femenino que es la imaginación. Ellos mueren y el mundo camina hacia el lado opuesto al de su muerte, esto es, hacia la frivolidad.

Por eso recordar de vez en cuando la vida y la obra de algunos de estos autores en medio de esa Pasarela Cibeles que es la actualidad, se vuelve ahora un acto subversivo.

Sé que los hombres pasan pero las palabras escritas quedan y, sin embargo, me confieso tan egoísta que a veces no me conformo con eso. No tengo ni idea de si no existe o está de vacaciones, pero ya de no presentársele a Dios una enmienda a la totalidad, que sería demasiado, que firme de una vez la bula para que ciertas personas imprescindibles no se mueran nunca.

Ahora ya nadie puede decir anda a Manuel Vázquez Montalbán, y eso resta bastante a todo lo que escribimos sobre él, pero sí podemos susurrárselo, por ejemplo, a Antonio Pereira... Te queremos. 